\title{
Weed coexistence periods in cassava varieties
}

\author{
Gustavo Moratelli ${ }^{1}$, Silvio Douglas Ferreira ${ }^{1 *} \oplus$, Hiago Canavessi ${ }^{1} \oplus$, \\ Fey Emerson ${ }^{1} \odot$, Marco Antonio Sedrez Rangel ${ }^{2}$, Neumárcio Vilanova da Costa $^{1}{ }^{1}$
1 Universidade Estadual do Oeste do Paraná, Marechal Cândido Rondon, PR, Brasil. E-mail: gustavo.moratell@gmail.com; agrosilvio@outlook.com; canavessi1996@hotmail.com; emerson.fey@unioeste.br; neumarciovc@hotmail.com
22Embrapa Mandioca e Fruticultura, Cruz das Almas, BA, Brasil. E-mail: marco.rangel@embrapa.br

ABSTRACT: The competition caused by weeds in the cassava culture significantly reduces their productive potential and consequently the profitability for the producer. Thus, the objective was to determine the period prior to interference (PPI) and the period prior to damage to economic yield (PPDEY) of weeds in cassava varieties. The design used was randomized blocks in factorial $2 \times 2 \times 12$, with four replications. The first factor was constituted by two varieties ('Baianinha' and 'Clone 56-03'), the second factor was constituted by the conditions of coexistence (with and without) of the crop with the weeds and the third factor corresponded to 12 periods $(0,20,40,60,80,100,120,140,160,180,200$, and 220 days after planting - DAP). 'Baianinha' was less tolerant of weed competition compared to 'Clone 56-03'. Considering the use of arbitrary and economic criteria of acceptable losses in the root productivities, the PPI and PPDEY of 11 and 65 DAP were determined for 'Baianinha' and 44 and 138 DAP for 'Clone 56-03', respectively. Likewise, considering the starch productivity data, the PPI and PPDEY of 8 and 21 DAP were determined for 'Baianinha' and 38 and 84 DAP for 'Clone 56-03', respectively.

Key words: cost of control; management strategies; Manihot esculenta; weed interference

\section{Períodos de convivência das plantas daninhas em variedades de mandioca}

RESUMO: A competição causada pelas plantas daninhas na cultura da mandioca reduz significativamente seu potencial produtivo e consequentemente a lucratividade para o produtor. Deste modo, objetivou-se determinar o período anterior à interferência (PAI) e o período anterior ao dano no rendimento econômico (PADRE) das plantas daninhas em variedades de mandioca. 0 delineamento utilizado foi blocos casualizados em fatorial $2 \times 2 \times 12$, com quatro repetições. 0 primeiro fator foi constituído por duas variedades (Baianinha e Clone 56-03), o segundo fator foi constituído pelas condições de convivência (com e sem) da cultura com as plantas daninhas e o terceiro fator correspondeu a 12 períodos $(0,20,40,60,80,100,120,140,160,180,200$ e 220 dias após plantio - DAP). A Baianinha foi menos tolerante a matocompetição em relação ao Clone 56-03. Considerando 0 uso de critérios arbitrários e econômicos de perdas aceitáveis nas produtividades de raízes foram determinados o PAI e PADRE de 11 e 65 DAP para a Baianinha e de 44 e 138 DAP para Clone 56-03, respectivamente. Do mesmo modo, considerando os dados de produtividade de fécula determinou-se respectivamente o PAI e PADRE de 8 e 21 DAP para a Baianinha e de 38 e 84 DAP para Clone 56-03.

Palavras-chave: custo de controle; estratégia de manejo; Manihot esculenta; matointerferência

\footnotetext{
* Silvio Douglas Ferreira - E-mail: agrosilvio@outlook.com (Corresponding author)

Associate Editor: Leandro Gallon
} 


\section{Introduction}

Cassava (Manihot esculenta Crantz) plays an important role in world food security, being the main source of basic food for about one billion low-income people in 104 countries (Latif \& Muller, 2015; FAO et al., 2020). Besides that, cassava can also be used as animal feed, as well as raw material for the starch industry, for medicines, cosmetics and as a source for the production of biofuels (Ozoegwu et al., 2017; Bi et al., 2018).

The potential for industrial uses has contributed to the increase, respectively, of 31.1 and $36.7 \%$ in the area under cultivation and in the production of cassava roots in the world, considering the period from 2000 to 2018 (FAO, 2020), but the average yield of root production $\left(11.4 \mathrm{t} \mathrm{ha}^{-1}\right)$ is low relative to the potential of 36.3 to $50,0 \mathrm{tha}^{-1}$ for growing seasons of 10 and 18 months, respectively (Streck et al., 2014).

Among the main problems that limit the productive potential of the cassava crop, the interference of weeds stands out (Costa et al., 2020a). However, there are studies that indicate that the crop can remain up to 25 days in coexistence with weeds (Period Prior to Interference - PPI), without damaging their development and root production (Johanns \& Contiero, 2006; Biffe et al., 2010). These periods are usually determined using arbitrary criteria such as an acceptable $5 \%$ loss in maximum crop yield. In practice, in some cases losses of $5 \%$ of crop production do not represent the real costs used in weed control, causing under- or overestimation of the PPI, and this, consequently, undermines the use of these indices as a criterion for decision making on whether or not to control weeds and reduces the guarantees of economic return to the crop.

In this way, Vidal et al. (2005), proposed to use the Period Prior to Damage to Economic Yield (PPDEY), as a way to use economic aspects, such as the cost of control and the amount paid for the harvested product, to establish acceptable periods of coexistence of the crop with the weed community before deciding to control it.

The establishment of criteria that help in weed control decision making should also be based on the knowledge of the tolerance level of varieties to coexistence with the weed community, since more competitive varieties can integrate management strategies and even reduce control costs (Moratelli et al., 2020).

Cassava breeding programs usually select varieties that are highly productive, disease resistant and adapted to mechanization (Cunha \& Farias Neto, 2016). However, selecting fast-growing varieties whose aboveground architecture reduces light penetration between the crop rows may suppress seed bank emergence (Jacob et al., 2016). Although this strategy does not avoid the need to use other control methods, it is noteworthy that due to the improvement in competitive abilities, these varieties can coexist longer with the weed community, which represents an important aspect in extensive areas of cultivation, since the producer can prioritize the management of areas according to varietal tolerance to matocompetition, besides allowing changes in the logistics of using available equipment and waiting for the ideal environmental conditions that ensure greater efficiency and safety of the control method to be used.

Embrapa Mandioca e Fruticultura has in its manihot improvement program several promising clones, which show fast growth and vigorous canopy. However, there is little information about the tolerance of these clones to coexistence with weeds. In the future, the use of more competitive varieties and the determination of criteria for weed control can contribute to the consolidation and sustainability of the cassava production chain.

Thus, considering only the period of the $1^{\text {st }}$ cycle of the crop (up to ten months), when the costs of weed control are usually more expensive, we aimed to determine the period prior to interference (PPI) and the period prior to damage to economic yield (PPDEY) of weeds for the traditional cassava variety 'Baianinha' and the promising clone of Embrapa Mandioca e Fruticultura 'Clone 56-03'.

\section{Materials and Methods}

The experiment was conducted over a period of ten months in the 2015/2016 harvest, in the municipality of Entre Rios do Oeste, Paraná, Brazil, in a cassava production area located in the following coordinates: $24^{\circ} 42^{\prime} 24^{\prime \prime} S, 54^{\circ} 14^{\prime} 36^{\prime \prime}$ $\mathrm{W}$ and $260 \mathrm{~m}$ of altitude.

The local soil was classified as Dystrophic Red Latosol (LVdf), with a clayey texture (Santos et al., 2018). The chemical analysis of the soil presented the following characteristics: $\mathrm{pH}$ $\mathrm{CaCl}_{2}=5.95 ; \mathrm{Al}^{3+}=0 \mathrm{cmol}_{\mathrm{c}} \mathrm{dm}^{-3} ; \mathrm{Ca}^{2+}=4.52 \mathrm{cmol}_{\mathrm{c}} \mathrm{dm}^{-3} ; \mathrm{Mg}^{2+}=$ $3.42 \mathrm{cmol}_{\mathrm{c}} \mathrm{dm}^{-3} ; \mathrm{P}=33.30 \mathrm{mg} \mathrm{dm}^{-3} ; \mathrm{K}=0.88 \mathrm{cmol}_{\mathrm{c}} \mathrm{dm}^{-3} ; \mathrm{OM}=$ $6.04 \mathrm{~g} \mathrm{dm}^{-3}, \mathrm{~V} \%=76.10 \%$.

The design used was randomized blocks in a $2 \times 2 \times 12$ factorial design with four repetitions. The first factor consisted of two varieties (Baianinha and Clone 56-03), the second by the conditions of coexistence (with and without) of the crop with the weeds and the third corresponded to 12 periods (0, $20,40,60,80,100,120,140,160,180,200$, and 220 days after planting - DAP). Each experimental unit consisted of four rows $8 \mathrm{~m}$ long, totaling an area of $28.8 \mathrm{~m}^{2}$.

The varieties were planted on $07 / 10 / 2015$ at $0.90 \times 0.60 \mathrm{~m}$ spacing, in no-till system under oat straw $\left(6.1 \mathrm{t} \mathrm{ha}^{-1}\right)$ and with $90 \%$ soil cover rate. No base fertilization (NPK) was performed at the time of cassava planting.

The phytosociological characterization of the weed community at the end of each coexistence period was performed using the inventory square method (BraunBlanquet, 1979), using metal frames of $0.25 \mathrm{~m}^{2}(0.5 \times 0.5 \mathrm{~m})$, randomly placed in each plot. The plants were collected, the species identified and the plant density $\mathrm{m}^{-2}$ calculated, then the Relative Importance index (RI) was determined, according to the formulas proposed by Mueller-Dombois \& Ellemberg (1974) and the Similarity Index (SI) according to an adaptation of Equation 1 proposed by Sorensen (1972). 


$$
\mathrm{SI}=\frac{2 \times \mathrm{NCSBE}}{\mathrm{NSE} A+\mathrm{NSE} B}
$$

where:

$$
\text { SI - Similarity Index; }
$$

NCSBE - number of common species in both environments; and,

NSE - number of species in environment.

The control of weeds in the plots submitted to the coexistence period was done by manual weeding at the end of each period.

To perform the evaluations of the coexistence and control periods, two manioc plants were collected in the penultimate position of the central rows of the plots, sectioned in parts, and taken to the laboratory to determine root productivity (t ha ${ }^{-1}$ ) and starch productivity ( $\mathrm{t} \mathrm{ha}^{-1}$ ).

Weighing for quantification of root yield was performed right after the plants were harvested. The starch yield was calculated after determining the starch content according to the method proposed by Oliveira et al. (2011).

The Period Prior to Damage to Economic Yield (PPDEY), was determined based on an adaptation of the method proposed by Vidal et al. (2005), considering Equation 2.

$$
\text { Acceptable loss }\left(\mathrm{t} \mathrm{h}^{-1}\right)=\frac{\mathrm{CC}\left(\mathrm{R} \$ \mathrm{ha}^{-1}\right)}{\operatorname{PC}\left(\mathrm{R} \$ \mathrm{t}^{-1}\right)}
$$

To calculate the acceptable loss $\left(\mathrm{t} \mathrm{ha}^{-1}\right)$ the costs of weed control were considered (CC) of R\$735.03 ha-1, determined based on the management adopted by manioc growers in the western region of Paraná in first cycle crops (Personal communication - COOATOL, Agrícola Horizonte, Herbioeste and CVALE), and the average marketing prices paid for cassava roots (PC) of $R \$ 332.89 \mathrm{t}^{-1}$ and of starch of $R \$ 1999.54 \mathrm{t}^{-1}$ in the extreme west of Paraná in the year 2019, according to data from CEPEA (2019).

In the no-till cassava system, the producers perform the desiccation of the cover crops with $1,080 \mathrm{~g} \mathrm{ha}^{-1}$ of glyphosate, at the time of planting in pre-emergence they apply a mixture of ametryn + clomazone $\left(1,500+1,000 \mathrm{~g} \mathrm{ha}^{-1}\right)$ and between 30 or 40 DAP of the cassava an application in post-emergence with $1,250 \mathrm{~g} \mathrm{ha}^{-1}$ of clomazone. The herbicide application cost of $\mathrm{R} \$ 30.00 \mathrm{ha}^{-1}$ was also considered.

For comparison, the Period Prior to Interference (PPI) was also determined, based on the arbitrary criterion of an acceptable $5 \%$ loss in root productivity (Biffe et al., 2010).

The climatic conditions of the experimental period are described in Figure 1.

The data obtained was subjected to regression analysis and the model was chosen based on the significance of the regression, passing the normality test, high $\mathrm{R}^{2}$ and biological logic.



Figure 1. Rainfall data $(\mathrm{mm})$ and monthly average temperature $\left({ }^{\circ} \mathrm{C}\right)$, during the experimental period. Entre Rios do Oeste, PR, Brazil (2015/2016).

\section{Results and Discussion}

Among the weeds observed in the experimental area during cassava cultivation, Euphorbia heterophylla, Bidens pilosa, Sorghum halepense, and Digitaria insularis stood out as the most important species in both varieties (Figure 2). The species $B$. pilosa and E. heterophylla were present in higher densities at the initial stages of development of both varieties of cassava, with higher values of Relative Importance (RI), being the most competitive species.

In 'Baianinha', D. insularis showed higher RI from 60 to 160 DAP, with average values of $30 \%$ (Figure 2A). After 120 DAP of coexistence, $S$. halepense had the highest RI, but the average value was $31 \%$. For 'Clone $56-03$ ', the highest RI values were

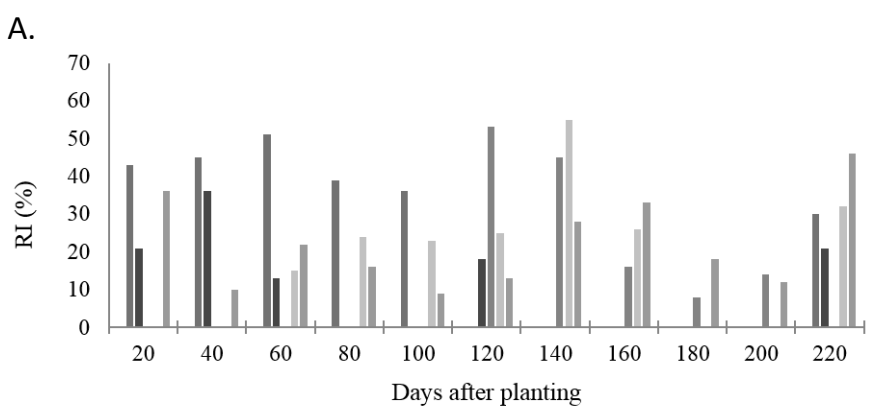

$\square$ Bidens pilosa $\square$ Euphorbia heterophylla $\square$ Sorghum halepense $\llbracket$ Digitaria insuaris $\square$ Outros B.



- Bidens pilosa $\square$ Euphorbia heterophylla $\square$ Sorghum halepense $\llbracket$ Digitaria insuaris $\llbracket$ Outros

Figure 2. Relative importance index (RI) of weeds present in each coexistence period in the varieties 'Baianinha' (A) and 'Clone 56-03' (B) in the $1^{\text {st }}$ cycle. 
from S. halepense and D. insularis starting at 120 DAP, which predominated until the end of the crop cycle (Figure 2B).

Weeds of the Asteraceae and Poaceae families are among the most important plants in the agricultural areas of Paraná. Such a situation was observed in a weed survey conducted in a region close to the site of the present study, in which plants of the Asteraceae family were found to have the highest relative importance (Ramella et al., 2020).

It is noteworthy that the weeds with higher RI observed in this experiment are all difficult to be controlled, mainly because they are resistant to herbicides such as glyphosate and other mechanisms of action (Takano et al., 2016; Ferreira et al., 2018).

Analysis of the Similarity Index showed a high homogeneity (85.7\%) of the weed species present in the plots of the varieties, showing that the degree of interference or competitiveness caused by the weed community was similar in both varieties (Table 1).

Weed interference caused a reduction in root yield (Figure 3 ) and starch yield of the cassava varieties (Figure 4). The highest root yield was presented by 'Baianinha' (12.73 $\left.\mathrm{t} \mathrm{ha}^{-1}\right)$, in the weed-free treatment. With the coexistence during the whole cycle of 'Baianinha', there was a $79.7 \%$ reduction in productivity compared to the weeded control. In 'Clone 56$03^{\prime}$ root yield was $9.85 \mathrm{t} \mathrm{ha}^{-1}$, with a $63.4 \%$ reduction at the end of the cycle for plants in competition. For starch yields, the reductions were 87.8 and $75.3 \%$ for 'Baianinha' and 'Clone 56-03', respectively.

In experiments carried out in the same region, losses in the productivity of cassava roots were also verified. However, these losses were cultivar dependent, with $38.9 \%$ in the 'Cascuda' variety (Costa et al., 2020b) and 63.5\% in the 'Baianinha' variety (Franciscon et al., 2016).

The acceptable loss caused by weed interference, considering economic criteria, represented $2.21 \mathrm{t} \mathrm{ha}^{-1}$ of root yield. Thus, considering the productivity of the varieties 'Baianinha' of $12.73 \mathrm{t} \mathrm{ha}^{-1}$ and 'Clone 56-03' of $9.85 \mathrm{t} \mathrm{ha}^{-1}$,

Table 1. Species densities and similarity index (SI) of weeds present in the plots of the variety 'Baianinha' and 'Clone 56$03^{\prime}$ throughout crop development ( $1^{\text {st }}$ cycle), in the 2015-2016 crop.

\begin{tabular}{lcc}
\hline \multirow{2}{*}{ Species } & 'Baianinha' & 'Clone 56-03' \\
\cline { 2 - 3 } & Density $\left(\right.$ plant m $^{-2}$ ) \\
\hline Avena sativa & 61 & 145 \\
Bidens pilosa & 232 & 200 \\
Commelina benghalensis & 15 & 33 \\
Conyza sp. & --- & 12 \\
Digitaria insularis & 26 & 36 \\
Euphorbia heterophylla & 98 & 62 \\
Ipomoea purpurea & --- & 3 \\
Leonurus sibiricus & --- & 17 \\
Phyllanthus niruri & 16 & 18 \\
Richardia brasiliensis & 4 & 3 \\
Sida spp. & 3 & 18 \\
Sorghum halepense & 35 & 27 \\
Similarity index (\%) & \multicolumn{2}{|}{85.7} \\
\hline
\end{tabular}

with control cost (CC) of $\mathrm{R} \$ 735.03 \mathrm{ha}^{-1}$ and the average of the marketing prices paid for the cassava roots (CP) of R\$ $332.89 \mathrm{t}^{-1}$, we determined the PPDEY of 65 and 138 DAP for the varieties 'Baianinha' and 'Clone 56-03', respectively.

However, in a scenario where the CC is high ( $R \$ 929.86$ $\mathrm{ha}^{-1}$ ), considering the adoption of the management strategy based on desiccation with the tank mixture of glyphosate + carfentrazone $\left(1,080+30 \mathrm{~g} \mathrm{ha}^{-1}\right)$, application at planting time of the ready mix of ametryn + clomazone $\left(1,500+1.000 \mathrm{~g} \mathrm{ha}^{-1}\right)$ and between 30 or 40 DAP of cassava an application of the tank mixture of clomazone + clethodim + mineral oil $(1,250+$ $108 \mathrm{~g} \mathrm{ha}^{-1}+0.5 \% \mathrm{v} / \mathrm{v}$ of mineral oil) and the same price paid for the roots ( $\left.R \$ 332.89 \mathrm{t}^{-1}\right)$, the PPDEY for root productivity becomes 80 DAP for 'Baianinha' and 154 DAP for 'Clone 56$03^{\prime}$.

In both simulations, the 'Clone 56-03' presented higher PPDEY. This condition is probably related to the fact that 'Clone $56-03$ ' is more competitive than 'Baianinha' and consequently tolerates a longer period of coexistence with the weed community. However, late control of weeds should be avoided even in competitive varieties, because late control becomes difficult due to the larger size of the cassava plants and weeds. What's more, weeds can produce and disperse their seeds, enriching the soil's seed bank.

By adopting the arbitrary value of $5 \%$ as an acceptable loss in root yield, the PPI of 11 DAP for 'Baianinha' and 44 DAP for 'Clone 56-03' was calculated.

For starch yields, the acceptable loss caused by interference considering the economic values represented $0.37 \mathrm{t} \mathrm{ha}^{-1}$. Based on the same values used for root yield data, the PPDEY estimate was 21 and 84 DAP for 'Baianinha' and 'Clone 56-03', respectively (Figure 4). Considering 5\% acceptable loss, the PPI for starch yield was determined at 8 DAP for 'Baianinha' and 38 DAP for 'Clone 56-03', being similar to those obtained using economic data from PPDEY.

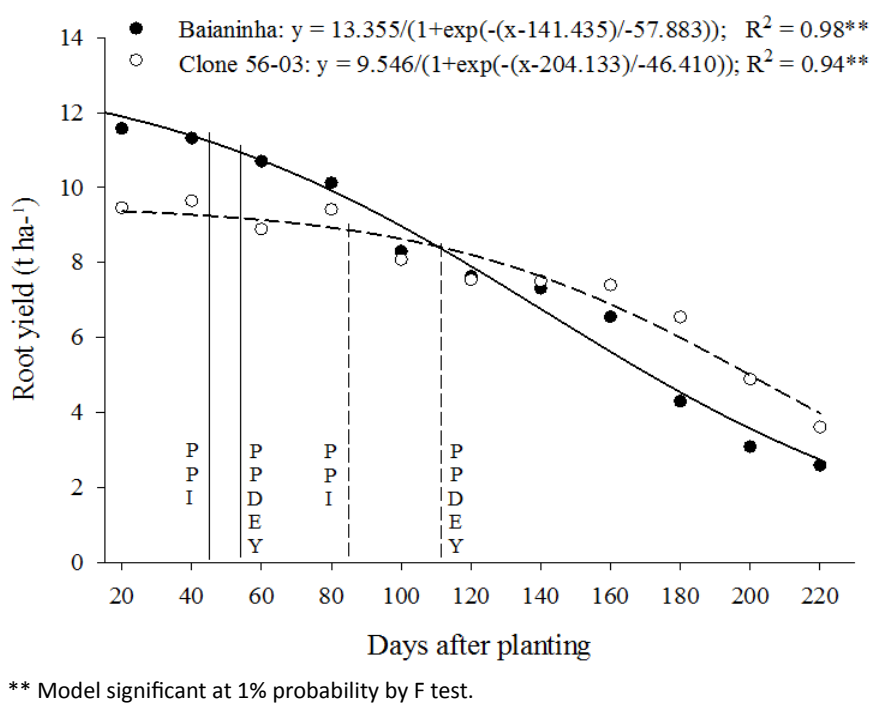

Figure 3. Estimation of the period prior to interference (PPI) and period prior to damage to economic yield (PPDEY) based on root yield of the varieties 'Baianinha' and 'Clone 56-03', in the $1^{\text {st }}$ cycle. 


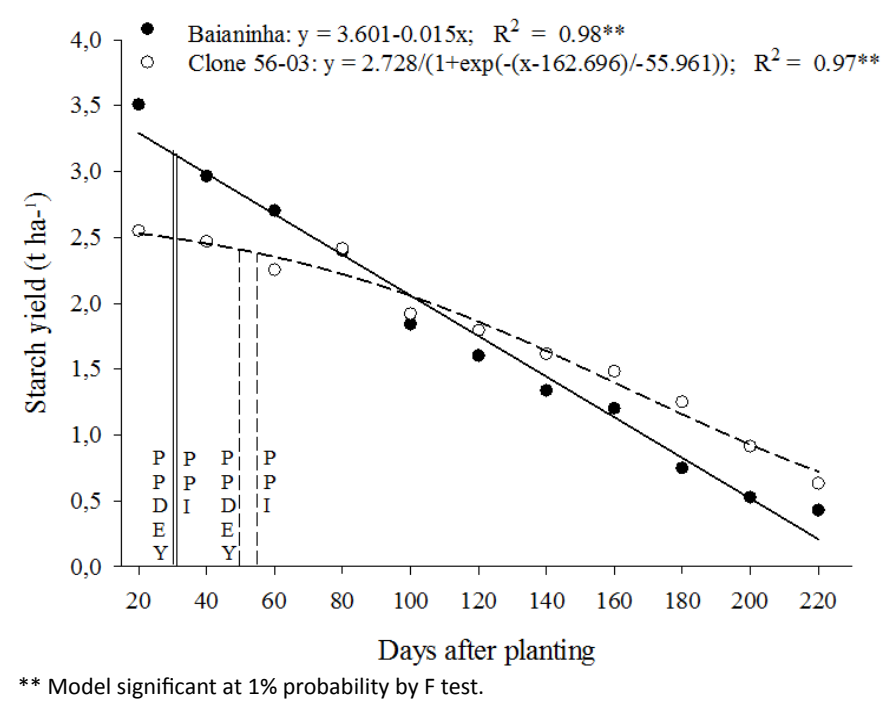

Figure 4. Estimation of the period prior to interference (PPI) and period prior to damage to economic yield (PPDEY) for starch yield of the varieties 'Baianinha' and 'Clone 56-03', in the $1^{\text {st }}$ cycle.

It is noteworthy that, in practice, it would be more interesting to use the PPI or the PPDEY based on starch data for decision making to control weeds, since they indicate the need for control at an earlier period than the data of PPI and PPDEY based on root yield. This can provide a higher yield for starch extraction in the industry, besides allowing the producer to choose cheaper control strategies due to the smaller size of the weeds (Vidal et al., 2005) and guarantee a higher economic return.

Overall, the PPI determined for root and starch yields for the cassava varieties in this study shows similarity with the results of experiments conducted under conventional soil preparation presented by Johanns \& Contiero (2006) (60 DAP) and Soares et al. (2019) (36 DAP). However, it is noteworthy that the cultivation of cassava in no-till over oat straw presents itself as a sustainable alternative, and may even dispense with the use of herbicides for weed control due to the formation of a physical barrier to the emergence of the seed bank and the release of allelopathic compounds (Otsubo et al., 2012). In addition to improving soil fertility due to nutrient cycling processes, reduction of temperature range and preservation of physical properties in the soil compared to conventional preparation (Gabriel Filho et al., 2000; Fasinmirin \& Reichert, 2011; Ramella et al., 2020). These factors may give cassava varieties competitive advantages over the weed community.

Differential competitive ability was observed among the varieties evaluated, since the clone 'Clone $56-03^{\prime}$ ' tolerated more time living with weeds (44 DAP) than 'Baianinha' (11 DAP) without significant decreases in root yield. This fact further evidences that matocompetition can be more harmful in highly productive varieties such as 'Baianinha'.

The PPI and PPDEY information can establish priorities in weed community control management according to the sensitivity of the variety to weed competition, which is an extremely valuable approach, especially when economic factors are considered to support control decisions. Another important aspect is that the crop production component that best allows the practical application of the use of interference periods should be considered, which in this study was starch yield.

\section{Conclusions}

Considering the use of arbitrary and economic criteria for acceptable losses in root yields, the period before interference (PPI) and period before damage to economic yield (PPDEY) of 11 and 65 DAP for 'Baianinha' and 44 and 138 DAP for 'Clone 56-03' were determined, respectively. Similarly, considering the starch yield data, PPI and PPDEY of 8 and 21 DAP for 'Baianinha' and of 38 and 84 DAP for 'Clone 56-03' were determined, respectively. The use of economic data for estimating PPDEY proved to be a better practical application for weed control decision making, especially when starch yield data were considered. In addition, despite being more productive 'Baianinha' was less competitive with weeds than 'Clone 56-03'.

\section{Acknowledgments}

This work was carried out with support from the Coordenação de Aperfeiçoamento de Pessoal de Nível Superior - Brazil (CAPES) - Funding Code 001.

\section{Compliance with Ethical Standards}

Author contributions: Conceptualization: GM, NVC; Data curation: GM, SDF, HC; Formal analysis: GM, NVC; Funding acquisition: MASR, NVC; Investigation: GM, SDF, HC, FE, NVC; Methodology: GM, FE, NVC; Project administration: FE, MASR, NVC; Resources: FE, MASR, NVC; Supervision: FE, NVC; Validation: GM, NVC; Visualization: GM, SDF, NVC; Writing original draft: GM, NVC; Writing - review \& editing: SDF, NVC.

Conflict of interest: The authors declared that there is no possible conflict of interest (professional or financial) that may influence the article.

Financing source: Coordenação de Aperfeiçoamento de Pessoal de Nível Superior - Brazil (CAPES) - Finance Code 001.

\section{Literature Cited}

Bi, I.R.D.; Kouassi, K.I.; Koffi, K.K.; Kouakou, K.L.; Baudoin, J.P.; Zoro, B.I.A. Evaluation of cassava varieties for weed tolerance ability. Experimental Agriculture, v.54, n.3, p.443-451, 2018. https://doi. org/10.1017/S0014479717000151.

Biffe, D.F.; Constantin, J.; Oliveira Jr., R. S.; Franchini, L.H.M.; Rios, F.A.; Blainski, E.; Arantes, J.G.Z.; Alonso, D.G.; Cavalieri, S.D. Período de interferência de plantas daninhas em mandioca (Manihot esculenta) no noroeste do Paraná. Planta Daninha, v.28, n.3, p.471-478, 2010. https://doi.org/10.1590/S010083582010000300003 . 
Braun-Blanquet, J. Fitosociologia; bases para el estudio de las comunidades vegetales. Madrid: H. Blume Ediciones. 820p.

Centro de Estudos Avançados em Economia Aplicada CEPEA. Preços da raiz e da fécula de mandioca. https://www.cepea.esalq.usp. $\mathrm{br} / \mathrm{br} /$ indicador/mandioca.aspx. 02 Jul. 2020.

Costa, N.V.; Salvalaggio, A.C.; Ferreira, S.D.; Barbosa, J.A.; Gibbert, A.M. Sequential application of herbicides alone and in mixture with and without foliar fertilizer after pruning of cassava plants. Planta Daninha, v.38, e020191376, 2020b. https://doi. org/10.1590/s0100-83582020380100004.

Costa, N.V.D.; Gibbert, A.M.; Ferreira, S.D.; Canavessi, H.; Salvalaggio, A.C. Strategies of chemical management for weed control in cassava. Revista Ceres, v. 67, n. 3, p. 240-246, 2020a. https://doi. org/10.1590/0034-737×202067030010.

Cunha, E.F.M.; Farias Neto, J.T. Melhoramento genético da mandioca para o estado do Pará. Embrapa Amazônia Oriental-Capítulo em livro científico (ALICE), 2016. https://www.alice.cnptia.embrapa. br/bitstream/doc/1056648/1/LVMandiocacap3.pdf. 19 Dez. 2020.

Fasinmirin, J.T.; Reichert, J.M. Conservation tillage for cassava (Manihot esculenta Crantz) production in the tropics. Soil \& Tillage Research, v.113, p.1-10, 2011. https://doi.org/10.1016/j. still.2011.01.008.

Ferreira, S.D.; Exteckoetter, V.; Gibbert, A.M.; Barbosa, J.A.; da Costa, N.V. Biological cycle of susceptible and glyphosate-resistant sourgrass biotypes in two growth periods. Planta Daninha, v.36, e018175923, 2018. https://doi.org/10.1590/s0100-83582018360100077.

Food and Agricultural Organization of the United Nations - FAO. FAOSTAT. Production quantities of Cassava by country. Average 2000-2018. http://www.fao.org/faostat/en/\#data/QC/visualize. 30 May. 2020.

Food and Agricultural Organization of the United Nations - FAO; International Fund for Agricultural Development - IFAD.; United Nations Children's Fund - UNICEF; World Food Programme - WFP; World Health Organization - WHO. The state of food security and nutrition in the World 2020. Transforming food systems for affordable healthy diets. Rome: FAO, 2020. 320p. https://doi. org/10.4060/ca9692en.

Franciscon, H.; Costa, N.V.; Rodrigues-Costa, A.C.P.; Ferreira, S.D.; Moratalli, G.; Salvalaggio, A.C.; Arrúa, M.A.M. Eficacia y selectividad de mezclas de herbicidas en el cultivo de mandioca. Revista de la Facultad de Agronomía, La Plata, v.115, n.2, p.209219, 2016. http://revista.agro.unlp.edu.ar/index.php/revagro/ article/view/742/502. 05 Nov. 2020.

Gabriel Filho, A; Pessoa, A. C. S.; Strohhaecker, L.; Helmich, J. J. Preparo convencional e cultivo mínimo do solo na cultura de mandioca em condições de adubação verde com ervilhaca e aveia preta. Ciência Rural, v. 30, n. 6, p .953-957, 2000. https:// doi.org/10.1590/S0103-84782000000600005.

Jacob, C. E.; Johnson, E. N.; Dyck, M. F.; Willenborg, C. J. Evaluating the competitive ability of semileafless field pea cultivars. Weed Science, v.64, n.1, p.137-145, 2016. https://doi.org/10.1614/ WS-D-15-00113.1.

Johanns, O.; Contiero, R.L. Efeitos de diferentes períodos de controle e convivência de plantas daninhas com a cultura da mandioca. Revista Ciência Agronômica, v.37, n.3, p.326-331, 2006. https:// doi.org/10.1590/S0100-83582018360100077.
Latif, S.; Müller, J. Potencial de folhas de mandioca na nutrição humana: uma revisão. Tendências em Ciência e Tecnologia de Alimentos, v.44, n.2, p.147-158, 2015. https://doi. org/10.1016/j.tifs.2015.04.006.

Moratelli, G.; Ferreira S.D.; Canavessi, H.; Fey, E.; Rangel, M.A.S.; Costa, N.V. Weed Interference on growth and leaf nutrient accumulation in two cassava varieties. Journal of Agricultural Studies. v.9, n.1, p.91-111, 2020. https://doi.org/10.5296/jas. v9i1.17879.

Mueller-Dombois, D.; Ellenberg, H. Aims and methods of vegetation ecology. New York: John Wiley \& Sons, 1974. 547p.

Oliveira, N.T.; Alves, J.M.A.; Uchôa, S.C.P.; Rodrigues, G.S.; Melville, C.C.; Albuquerque, J.A.A. Caracterização e identificação de clones de mandioca produzidos em Roraima para consumo in natura. Agroambiente, v.5, n.3, p.188-193, 2011. https://doi. org/10.18227/1982-8470ragro.v5i3.624.

Otsubo, A. A., Brito, O. R., Passos, D. P., Araújo, H. S., Mercante, F. M. E Otsubo, V. H. N. Formas de preparo de solo e controle de plantas daninhas nos fatores agronômicos e de produção da mandioca. Semina: Ciências Agrárias, v. 33, n. 6, p. 2241-2246, 2012. https://doi.org/10.5433/1679-0359.2012v33n6p2241.

Ozoegwu, C.G.; Eze, C.; Onwosi, C.O.; Mgbemene, C.A.; Ozor, P.A. Biomass and bioenergy potential of cassava waste in Nigeria: Estimations based partly on rural-level garri processing case studies. Renewable and Sustainable Energy Reviews, v.72, p.625-638, 2017. https://doi.org/10.1016/j.rser.2017.01.031.

Ramella, J.R.P.; Barbosa, J.D.A.; Ferreira, S.D.; Fey, E.; Costa, N.V.D. Weed interference on nutrient accumulation in the leaves of cassava under no-tillage or conventional tillage. Pesquisa Agropecuária Brasileira. v.55, e01750, 2020. https://doi. org/10.1590/S1678-3921.pab2020.v55.01750.

Santos, H.G.; Jacomine, P.K.T.; Dos Anjos, L.H.C.; De Oliveira, V.A.; Lumbreras, J.F.; Coelho, M.R.; Almeida, J.A.; Araújo Filho, J.C.; Oliveira, J.B.; Cunha, T.J.F. Sistema Brasileiro de Classificação de Solos. 5.ed. Brasília: Embrapa Produção de Informação, 2018. 353p.

Soares, M.R.S.; José, A.R.S.; Nunes, R.T.C.; Silva, R.D.A.; Caetano, A.P.O.; Oliveira, D.S.D.; Nolasco, C.A.; Rampazzo, M.C. Períodos de interferência de plantas infestantes na cultura da mandioca, submetida ou não à adubação NPK, em Vitória da Conquista-BA. Revista de Ciências Agrárias, v.42, n.1, p.231240, 2019. https://doi.org/10.19084/RCA18166.

Sorensen, T. A method of establishing groups of equal amplitude in plant sociology based on similarity of species content, and its application to analyses of the vegetation on Danish commons. Copenhage: I Kommission Hos E. Munksgaard, 1948. 34p. (Det Kongelige Danske Videnskabernes Selskab. Biologiske Skrifter, v.5, n.4). http://www.royalacademy.dk/ Publications/High/295_S\%C3\%B8rensen,\%20Thorvald.pdf. 15 Oct. 2020.

Streck, N.A.; Pinheiro, D.G.; Zanon, A.J.; Gabriel, L.F.; Rocha, T.S.M.; Souza, A.T.; Silva, M.R. Efeito do espaçamento de plantio no crescimento, desenvolvimento e produtividade da mandioca em ambiente subtropical. Bragantia, v.73, n.4, p.407-415, 2014. https://doi.org/10.1590/1678-4499.0159. 
Takano, H.K.; Oliveira Junior, R.S.D.; Constantin, J.; Braz, G.B.P.; Franchini, L.H.M.; Burgos, N.R. Multiple resistance to atrazine and imazethapyr in hairy beggarticks (Bidens pilosa). Ciência e Agrotecnologia, v.40, n.5, p.547-554, 2016. https://doi. org/10.1590/1413-70542016405022316.
Vidal, R.A.; Fleck, N.G.; Merotto Jr., A. Período anterior ao dano no rendimento econômico (PADRE): nova abordagem sobre os períodos de interferência entre plantas daninhas e cultivadas. Planta Daninha, v.23, n.3, p.387-396, 2005. https://doi. org/10.1590/S0100-83582005000300001. 